\title{
Migration routes and stopover sites of the Eurasian Spoonbill (Platalea leucorodia) between the Carpathian Basin and wintering areas
}

\author{
Csaba PigniczKi ${ }^{1 *}$, Jelena KRALJ ${ }^{2}$, Stefano Volponi ${ }^{3}$, Antun \\ ŽUlJević ${ }^{4}$, Mohamed-Ali DaKhli ${ }^{5,6}$, Tibor MikusKa ${ }^{7}$, Hichem \\ AZAFZAF $^{6} \&$ Zsolt VÉGVÁRI $^{8}$
}

Received: February 23, 2016-Accepted: May 15, 2016

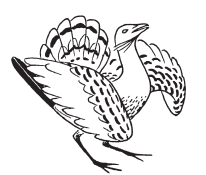

Csaba Pigniczki, Jelena Kralj, Stefano Volponi, Antun Žuljević, Mohamed-Ali Dakhli, Tibor Mikuska, Hichem Azafzaf \& Zsolt Végvári 2016. Migration routes and stopover sites of the Eurasian Spoonbill (Platalea leucorodia) between the Carpathian Basin and wintering areas. - Ornis Hungarica 24(1): 128-149.

\begin{abstract}
Understanding the migration routes of the Central European Spoonbill population is important for their conservation. Here we analysed movements of 3186 individuals of Eurasian Spoonbills marked with colour rings in the Carpathian Basin (Hungary, Croatia and Serbia) between 2003 and 2015, and a satellite tagged individual, which was equipped in Italy in 2013, and later moved to the Carpathian Basin. Migration routes of these Spoonbills predominantly followed the Adriatic Flyway, however, some birds were also found to both east and west from this flyway. We identified 59 stopover sites, 55 of which were located along the Adriatic Flyway. Colourringed juveniles (1cy), on average, spent 4.0 \pm 0.9 (SE) days on the stopover sites along the Adriatic Flyway during autumn migration, while non-juveniles ( $>1 \mathrm{cy}$ ) spent $2.6 \pm 1.0$ (SE) days during autumn and $2.1 \pm 0.4$ (SE) days during spring migration there. These durations were not significantly different. Duration of stops of the satellite tracked individual was between 7 and 15 days during autumn and between 1 and 12 days during spring migration. Our results indicate the existence of two alternative routes of the Adriatic Flyway between the Carpathian Basin and the wintering areas in southern Italy and the central part of coastal North-Africa. The North-Adriatic Flyway includes stopover sites in north-eastern Italy at the river mouth of River Isonzo, Lagunes of Venice and wetlands around River Po. The South Adriatic Flyway leads through the Balkan Peninsula, with stopover sites at the karst lakes of Bosnia and Herzegovina, mouth of the river Neretva (Croatia), Ulcinj Salinas (Montenegro) and wetlands in Gulf of Manfredonia (Italy). This hypothesis was also supported by the migration of the satellite tagged individual, the paths of which was described here in detail. The average coordinates of spring and autumn stopover sites were located at different parts of the flyway: it was in south-western Italy during autumn migration, while it was close to the western coast of the Balkan Peninsula during spring migration. We found examples for Spoonbills using the same migration paths along the same route year by year on both spring and autumn migration, but also noticed shifts between routes. Some observations indicate that individuals may show site fidelity to stopover sites between years, although the sample size was low for statistical significance.
\end{abstract}

Keywords: colour ring, GPS tracking, nature conservation, Black Sea/Mediterranean Flyway, Adriatic Flyway

Összefoglalás A kanalasgémek vonulási útvonalának ismerete lényeges a védelmük szempontjából. Ebben a dolgozatban 3186 színes gyürüvel jelölt és egy jeladós kanalasgém vonulását elemeztük. Ezeket a madarakat 2003 és 2015 között a Kárpát-medencében (Magyarországon, Horvátországban és Szerbiában) gyürüzték, míg a jeladót 2013-ban Olaszországban helyezték fel, ez a madár később a Kárpát-medencében is felbukkant. A Kárpát-medencei kanalasgémek vonulásuk során elsődlegesen az adriai vonulási utat követték, de kisebb számban ettől keletre és nyugatra is megjelentek. Összesen 59 megállóhelyet határoztunk meg, melyböl 55 az adriai vonulási útvona-

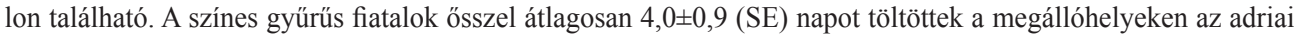




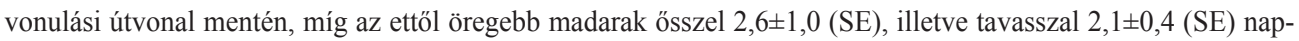
ra álltak meg. Ezek az értékek nem különböztek szignifikánsan. A jeladós madár ősszel 7-15, míg tavasszal 1-12 napra állt meg. Az adriai vonulási úton belül két alternatív út létezik a Kárpát-medence, illetve a dél-olaszországi és észak-afrikai telelőhelyek között. Az észak-adriai ág megállóhelyei Északkelet-Olaszországban az Isonzó torkolatánál, a Velencei-lagúnákon és a Pó körüli vizes élőhelyeken találhatóak. A dél-adriai ág a Balkán-félszigeten vezet át, megállóhelyei a Bosznia-Hercegovina területén elhelyezkedő karszt-tavakon, a Neretva torkolatában (Horvátország), az Ulcinj (Montenegró) melletti sólepárlókon találhatóak és a Manfredóniai-öböl (Olaszország) vizes élőhelyein. Ezt a mintázatot a jeladós madár követése is alátámasztotta. Az őszi és a tavaszi koordináták átlagai eltérnek: összel Délnyugat-Olaszországra, míg tavasszal a Balkán-félsziget nyugati partvidékére esnek. A madarak egy része évröl-évre ugyanazon a vonulási ágon vonul összel és tavasszal is, de ismert olyan egyed is, ami két szezonban különböző ágon vonult. Vannak a megállóterület-hüségre utaló adatok, de a mintaszám alacsony volt a statisztikai különbségek kimutatásához.

Kulcsszavak: színes gyürü, GPS nyomkövetés, természetvédelem, fekete-tengeri/mediterrán vonulási út, adriai vonulási út

${ }^{1}$ Kiskunság Bird Protection Society, 6070 Izsák, Hunyadi u. 29., Hungary, e-mail: csaba.spoonbill@gmail.com ${ }^{2}$ Institute of Ornithology, Croatian Academy of Sciences and Arts, 10000 Zagreb, Gundulićeva 24., Croatia

${ }^{3}$ Istituto Superiore per la Ricerca e la Protezione Ambientale (ISPRA), Via Ca' Fornacetta 9, 40064 Ozzano Emilia BO, Italy

${ }^{4} 25000$ Sombor, Vere Gucunje 20., Serbia

${ }^{5}$ Birding Tunisia, Cité La Jeunesse, 8045 El Haouaria, Tunisia

"Association "Les Amis des Oiseaux" (BirdLife Tunisia), Ariana Center, Bureau C 208/209, Ariana, 2080, Tunisia

${ }^{7}$ Croatian Society for the Bird and Nature Protection, I. 31000 Osijek, Gundulića 19a, Croatia

${ }^{8}$ Department of Conservation Zoology, University of Debrecen, 4032 Debrecen, Egyetem tér 1., Hungary

* corresponding author

\section{Introduction}

Avian migration is a regular, endogenously controlled, seasonal movement of birds between breeding and non-breeding areas. Migration includes two trips: from breeding grounds to non-breeding grounds and back (Salewski \& Bruderer 2007). These journeys are repeated in the same time of the year (Newton 2008).

Three major flyways used by shorebirds have been recognised between Eurasia and Africa together with the Middle East (Stroud et al. 2004). The East Atlantic Flyway runs along the Atlantic coasts of Europe and Africa (Stroud et al. 2004, Triplet et al. 2008). The West Asian/East African Flyway links the central Siberian tundra to the Caspian Sea, the Middle East (especially the Gulf Region) and eastern and southern Africa (Stroud et al. 2004, Schneider-Jacoby 2008). The Black Sea/Mediterranean Flyway joins arctic and boreal regions with final destinations in the Mediterranean Basin and West Africa (Stroud et al. 2004). The Black Sea/Mediterranen Flyway is used not only by shorebirds, but also by several other waterbird species during their migration. This flyway is the only one that crosses the Mediterranean Basin. Part of the Black Sea/Mediterranean Flyway is referred to as the Adriatic or Central European Flyway, which is one of the most important flyways for Central European waterbirds (Schneider-Jacoby 2008, Stumberger \& Schneider-Jacoby 2010). The wintering areas of waterbirds along the Adriatic Flyway are found at the Mediterranean coast, mainly in Tunisia, but large number of birds may continue the migration to 
the Niger Basin after crossing the Sahara (Schneider-Jacoby 2008, Stumberger \& Schneider-Jacoby 2010).

Birds usually do not choose the most direct and shortest routes during their migration, but rather fly along detours (Alerstam 2001). For example, birds preferably migrate along detours to avoid crossing large barriers (desert, large mountains, sea) (Alerstam 2001, Alerstam et al. 2003). Several other factors affect the decision to take detours, including differences in wind and weather conditions, availability of stopover sites, risk of predation and starvation, drift and disorientation (Alerstam 2001).

A number of sites between breeding and non-breeding areas, called stopover or staging sites, connect migratory paths during bird migration (Navedo et al. 2010b, Warnock 2010). These are important for birds as feeding, drinking, moulting and resting sites (Kirby et al. 2008, Navedo et al. 2010b, Warnock 2010). These are also used during stochastic adverse weather events as emergency sites as these areas often provide shelter for migrating birds (Overdijk \& Navedo 2012). There are three main strategies in the use of stopover or staging sites, regarding the duration of stay and the distance between sites: hopping, skipping and jumping. Birds employing hopping or skipping strategies have short stops (often only for few of days) and relatively short subsequent flights to the next stop with relatively low fuelling rates and fuel loads. The distance between sites can be as large as hundreds of kilometres, with the distance covered by hoppers being shorter than that covered by skippers. Areas used by birds with hopping or skipping strategies have been referred to as stopover areas (Warnock 2010). In contrast, jumpers that cross barriers during their migration, where there is little chance of stopping, usually carry large amount of fuel that exceeds the optimally predicted amounts. To accumulate this fuel, birds usually stay on staging sites for longer periods (often for weeks), and they usually fly thousands of kilometres after departure (Warnock 2010).

Migratory waterbirds usually find only some patchily scattered stopover and staging areas and, the distances among these are usually relatively large. This is especially true for long-distance migrants (Navedo et al. 2010a, 2010b). A large number of bird species and individuals use these sites during an energetically demanding part of their annual cycle, therefore, it is important to identify and protect these stopover and staging sites. Additionally, conditions experienced at stopover or staging sites may affect not only the success of migration, but also future individual survival and reproduction, often referred to as carry-over effect, with potential consequences for population dynamics (Navedo et al. 2010b, Warnock 2010).

The Eurasian Spoonbill (Platalea leucorodia) has a large breeding area spanning between the Atlantic coast of Europe and the Pacific coast of Asia with two small populations in sub-Saharan Africa (Triplet et al. 2008). The Spoonbill is a specialist waterbird, largely depending on the presence of wetlands with water of suitable depth, as they are able to forage only in shallow water (Pigniczki \& Végvári 2015).

A part of the Central European Spoonbill population breeds in the Carpathian Basin with the largest population located in Hungary. Large numbers (100+ pairs) of breeders are also found in Austria, Croatia and Serbia, while only small populations exist in Slovakia, and irregular breeders in small numbers occur in western Romania (Pigniczki \& Végvári 2015). Spoonbills also breed regularly in the Czech Republic, from where birds migrate across the 
Carpathian Basin (Cepák 2008). Spoonbills from Central Europe winter mainly in Tunisia, with a large number of wintering individuals also found in Italy. Only a few wintering individuals are known from Turkey, Greece, Egypt, Sudan, Libya, Algeria, Morocco, sub-Saharan Africa between Niger and Mauritania, as well as from the Carpathian Basin (Pigniczki 2009, 2010, 2015, Kralj et al. 2012, Pigniczki \& Karcza 2013).

The Eurasian Spoonbill is a characteristic species of the Adriatic Flyway (Schneider-Jacoby 2008, Pigniczki 2010, Kralj et al. 2012), thus Schneider-Jacoby (2008) recommended it as one of the flagship species along this flyway to improve the protection of key sites. The Spoonbill is an umbrella species (Pigniczki \& Végvári 2015) and this increases the need for the conservation of its habitats used around the entire annual cycle. Although its main stopover sites have already been identified in the northern part of West Balkan between Slovenia and Northwest Albania (Stumberger et al. 2013), information on migration routes and other stopover sites are still missing (Schneider-Jacoby 2008) and knowledge of the connectivity among different stopover sites along the flyways is very limited.

The aims of this study were to (1) identify the migration routes, stopover and staging areas of the Central European Spoonbill population using individually marked individuals, and (2) identify the possible connection of those wetlands.

\section{Materials and Methods}

We used resights of colour-ringed Spoonbills marked as chicks in the Carpathian Basin for our analyses. The original database consists of 6867 recovery and resight records of 3186 individuals spanning between 2003 and 2015 in 13 cohorts. 1750 individuals were marked in Hungary (54.9\%), 751 were ringed in Croatia (23.6\%), while 685 were marked in Serbia $(21.5 \%)$.

The colour-ringing program, started in Hungary, Croatia and Serbia in 2003 (Pigniczki 2010, Kralj et al. 2012), has used three different types of colour-ringing schemes: (1) two engraved plastic rings with two characters of an alphanumerical code; some possible combinations of six colours on the two rings; used between 2003 and 2008; (2) colour combinations of six rings with a flag; six possible colours on rings; used between 2007 and 2009, and (3) a white engraved plastic ring with three or four characters of alphanumerical code with a possible use of a bar code; used since 2009.

Further data were obtained from an adult female equipped with a GPS-GSM transmitter (model DUCK 3 produced by Ecotone Telemetry) and ringed with metal and an engraved plastic ring. The bird was captured at the nest in the Comacchio lagoons in Italy in June 2013. The transmitter provided accurate information on the geographical location of the bird once every $0.5-6 \mathrm{~h}$ (usually every 2 or $4 \mathrm{~h}$ ). The sampling intervals were manually changed via an online panel accordingly to season and location to optimise control frequency of SMS delivery and battery usage.

We used the calendar year age category for each record as follows: a bird is one year old ( $1^{\text {st }}$ calendar year old, hereafter $\left.1 \mathrm{cy}\right)$ in the year of hatching until the $31^{\text {st }}$ of December that year; two years old (in its $2^{\text {nd }}$ calendar year, hereafter $2 \mathrm{cy}$ ) after the year of hatching, and so 
on. We defined five different age-groups: one year old Spoonbills (1cy or juveniles); two and three year old birds (2cy and 3cy or immature); four year old birds (4cy or sub-adults) and finally, birds older than four years (4+ or adults). Our preliminary results suggest that four year old (4cy) Spoonbills in the Pannonian population do not breed or, if they do, they breed in very low proportions (Pigniczki 2010, Pigniczki \& Végvári 2015).

Resighting data were collected opportunistically by an international network of amateur and professional birdwatchers and bird photographers scattered along the flyways and across the wintering areas. In addition, six colour-ring-reading expeditions were organised to Tunisia between November and February to find wintering birds in 2010, 2012, 2013 (two times) and 2014 (two times), and one was targeted the western Balkans between late September and mid-October of 2014 to check possible stopover sites. In Tunisia and Libya, during the International Waterbird Census (IWC), special attention was given to look for Spoonbills with colour-rings and to read the combination of colour and code.

We used stopover and wintering records of $1 \mathrm{cy}$ as well as records of 2cy birds seen until the end of March, as this is the end of the first-winter period, during which birds undertake their first migration to their wintering areas from the Carpathian Basin. We also used the records of 4cy individuals, and adults (4+), as they return to the natal area in high frequencies. We used all the stopover records of Spoonbills from the age of 4cy, because they return to their general natal or breeding area, the Carpathian Basin. Our observations confirmed this, because a large proportion of subadults and adults was found in the natal area during summer, but birds from these age groups were rarely observed in the stopover zones or wintering sites during breeding time. We only used the records of those immatures that returned to their natal area in the Carpathian Basin. Movements of immature birds (2cy and 3cy), unlike that of adults and subadults, are often not considered migratory: these individuals can stay on the wintering grounds or move northwards, but usually do not reach their natal grounds as they do not breed that year (Pigniczki 2009, 2015, Pigniczki \& Végvári 2015). Due to similar reasons, we excluded one record of a 4 cy individual from our analysis, because that individual was observed only in western Europe.

We used two approaches to identify migratory paths. The direct approach uses observations from the natal/breeding, stopover and wintering areas collected during the same migratory season from the same year. The indirect approach defines supposed paths as observations from the natal/breeding, stopover and wintering sites of one individual from different years. Spoonbills often show fidelity to their wintering areas after their first winter (Lok et al. 2011), and we also found site fidelity to the Carpathian Basin as breeding area (Pigniczki \& Végvári 2015), so we assumed those locations are used year by year by the same individuals.

Most of the wintering areas of Spoonbills from the Carpatian Basin are found below the latitude of $42^{\circ} \mathrm{N}$ (Pigniczki 2015). A Spoonbill was treated as wintering bird in a particular area, if: (1) it was observed between November and January at any age; (2) in the case of 2cy and 3cy birds, we treated data from February and March also as indicators of wintering; and if (3) a subadult or an adult bird was seen in October, but known to be present on the same location for at least 50 days before or after that observation. Similarly, (4) a sub-adult or an adult bird that was seen in February and that stayed for at least 30 days on the same location before or after the observation was also treated as wintering record. 


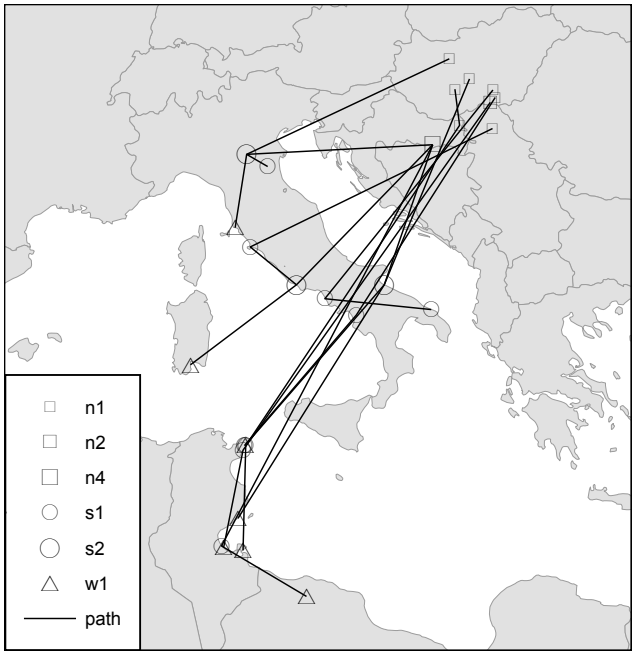

Figure 1. Migration paths (lines) of Spoonbills between the Carpathian Basin (n1, n2, n4) and the wintering location (w1) including stopover sites (s1, s2) during autumn migration within one migration season for each individual. The numbers after the letters indicate the number of individuals

1.ábra Kanalasgémek őszi vonulási útvonalai (vonal) a Kárpát-medence (n1, n2, n4) és a telelőhelyek (w1) között a megállóhelyekkel (s1, s2), egy vonulási szezonon belüli megfigyelések alapján, egyedenként. A jelölések mellett a számok az egyedszámot jelentik

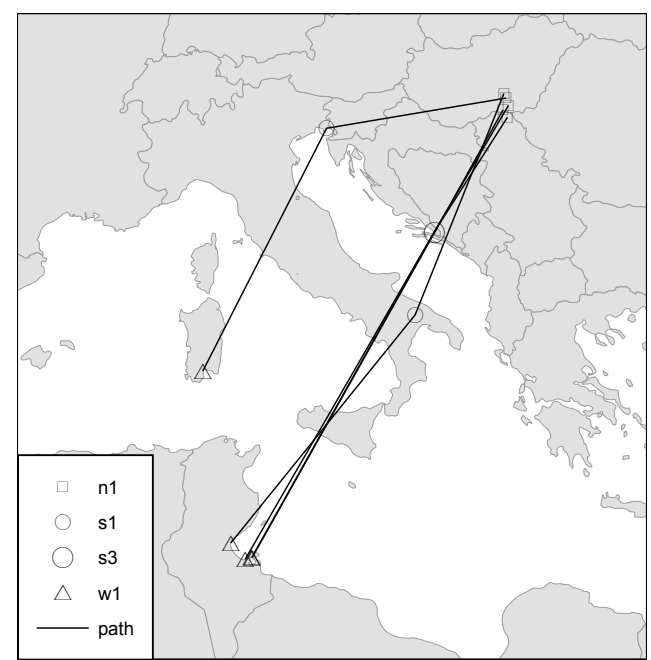

Figure 2. Migration paths (lines) of Spoonbills between the wintering location (w1) and the Carpathian Basin (n1) including stopover sites (s1, s3) during spring migration within one migration season for each individual. The numbers after the letters indicate the number of individuals

2. ábra Kanalasgémek tavaszi vonulási útvonalai (vonal) a telelőhelyek (w1) és a Kárpát-medence ( $\mathrm{n} 1)$ között a megállóhelyekkel (s1, s3), egy vonulási szezonon belüli megfigyelések alapján. A jelölések mellett a számok az egyedszámot jelentik

We classified spring stopovers where birds were observed between February and May for subadults and adults, and autumn stopovers where records came from a period between June and October for juveniles, sub-adults and adults. These periods were used also in the case of immature birds, but only for those that returned to the Carpathian Basin.

Using this approach, we analysed 201 stopover and migration records of 119 colour ringed individuals. We obtained information on (1) both wintering areas and a single stopover site in the case of 34 individuals, or (2) two stopover sites in the case of five specimens, or (3) two distinct wintering sites of one individual in connection with a wintering area shift, which together allowed us to identify 42 migration paths (16 by direct approach and 26 indirectly), as two individuals were seen at stopover sites in two different seasons.

To calculate average coordinates, we treated spring and autumn migrations separately. Observations of the same individuals from one location were considered only once. Data received from the bird with satellite transmitter were not included in this analysis.

When calculating the number of days spent at the stopovers, we treated two localities as one stopover site, if the same individual was observed in both of them, and the distance 


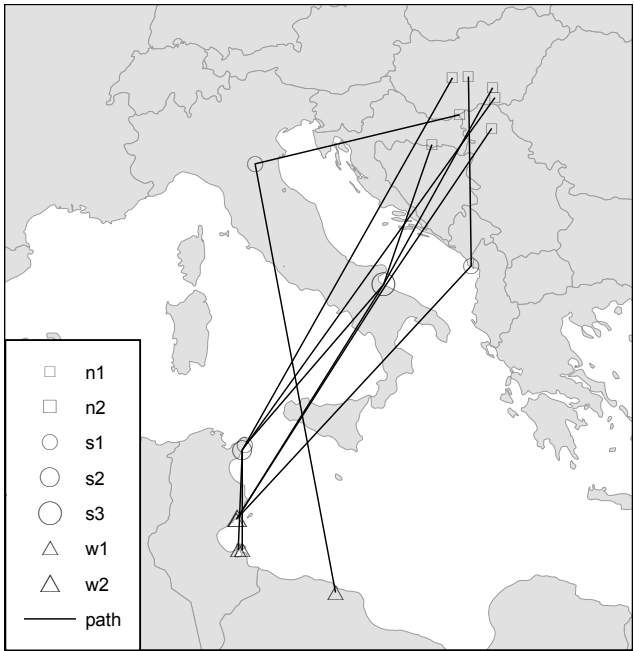

Figure 3. Migration paths (lines) of Spoonbills between the Carpathian Basin (n1, n2) and the wintering locations ( $w 1, w 2)$ including stopover sites $(s 1, s 2, s 3)$ during autumn migration with observations from different years. The numbers after the letters indicate the number of individuals

3. ábra Kanalasgémek őszi vonulási útvonalai (vonal) a Kárpát-medence $(\mathrm{n} 1, \mathrm{n} 2)$ és a telelőhelyek (w1, w2) között a megállóhelyekkel (s1, s2, s3), különböző évekből származó megfigyelések alapján. A jelölések mellett a számok az egyedszámot jelentik

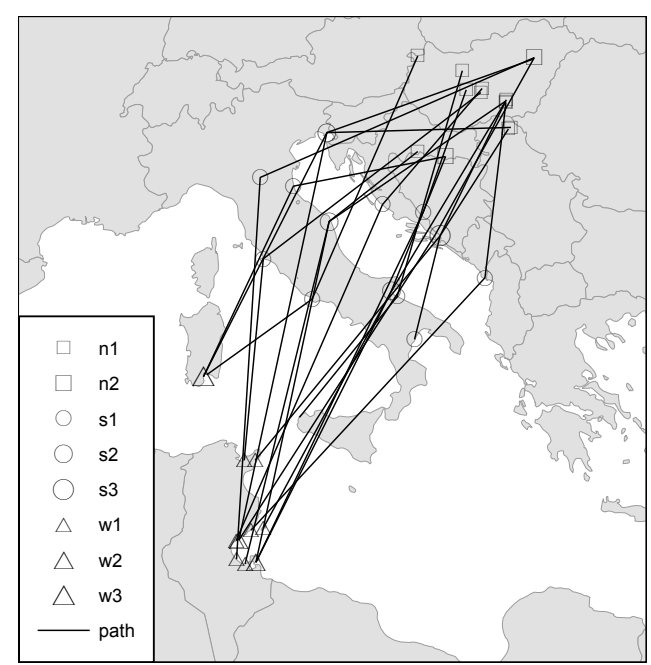

Figure 4. Migration paths (lines) of Spoonbills between the wintering location (w1, w2, w3) and the Carpathian Basin (n1, n2) including stopover sites (s1, s2, s3) during spring migration with observations from different years. The numbers after the letters indicate the number of individuals

4. ábra Kanalasgémek tavaszi vonulási útvonalai (vonal) a telelőhelyek (w1, w2, w3) és a Kárpát-medence $(n 1, n 2)$ között a megállóhelyekkel (s1, s2, s3), különböző évekből származó megfigyelések alapján. A jelölések mellett a számok az egyedszámot jelentik

between the two localities was not more than $50 \mathrm{~km}$. Spoonbills are rather mobile birds and may cover up to $50 \mathrm{~km}$ between feeding sites, or between feeding and roosting sites during their regular daily movements. It is difficult to estimate the real length of stopover duration of colour ringed individuals, as we suppose there was no possibility for the observers to regularly follow the birds in all cases. Probably, in most occasions the observations were casual, and that is why a lot of stopover durations were detected as one-daylong stays. Therefore these data probably do not provide exact values, but may indicate the minimum length of stopover. We calculated the mean values and standard errors (SE) to describe the differences between age groups (juvenile and non-juvenile) and migration seasons (spring and autumn), but the distribution of the data was not normal in any of these cases.

We used only records raising no doubts about the circumstances of the observations.

All statistical analyses were performed using the PAST statistical software (Hammer et al. 2001). 


\section{Results}

\section{Colour-ringed Spoonbills}

Our results suggested 16 distinct, direct migration paths of 16 individuals, which were observed within one autumn or one spring migration season (Figure 1, 2). Further, using the indirect approach, from movements of 24 individuals we outlined another 26 paths during the autumn and spring migration (Figure 3, 4, 5).

We identified 59 stopover sites of the Central European Spoonbill population of 118 individuals (this number does not include the observation of wintering area shift in West Africa). 39 stopover sites were used during autumn migration, while 24 on spring migration. Only four of them were used on both spring and autumn migrations (Figure 6, 7).

We analysed the stopover localities of 119 individuals (including the individual which wintered in West Africa). 55 stopover sites were identified along the Adriatic Flyway, used by 114 individuals (95.8\% of 119). Four stopover sites were found east of the Adriatic Flyway, used by four individuals (3.4\% of 119$)$. We know of only one individual $(0.8 \%$ of 119$)$ that was seen on the East Atlantic coast of Africa, which started to spend its first winter in Morocco, and was observed later in Mauritania until its 6cy (Figure 5).

Our findings indicate the existence of two main routes in the Adriatic Flyway (Figure 1, 2, 3, 4). One of them starts in the Carpathian Basin and proceeds south of the Alps to the north

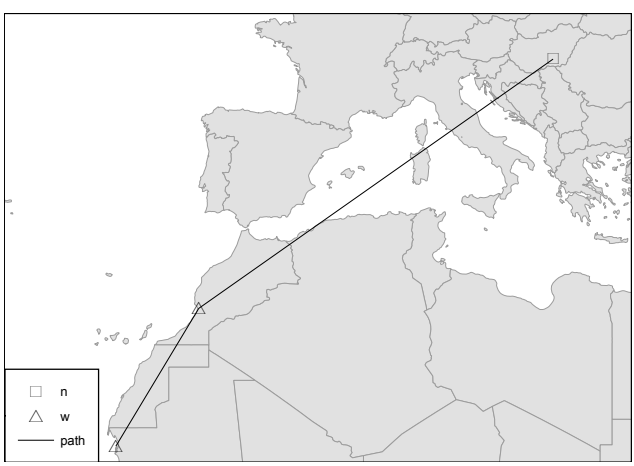

Figure 5. Migration route (line) of a Spoonbill (B/W [TN]) from the Carpathian Basin (n) with shift in its wintering locations (w). The individual was seen in Morocco in its first winter (juvenile), but was observed as a wintering individual in Mauritania in its second winter (immature) and 6cy-old adult age

5. ábra A B/W [TN] kódú kanalasgém vonulási útvonala (vonal) a Kárpát-medencéből (n) telelőhely-váltással (w). Első telesként (fiatal) Marokkóban figyelték meg, de második telesként (immatur) és hatodik naptári éves öreg madárként már Mauritániában azonosították mint telelő egyedet of Italy, then further to Sardinia, Tunisia and probably also to south Italy, Libya and Algeria, referred to as North-Adriatic Flyway. The other route leads across the Bosnian karst lakes, to the coastal area between the $\mathrm{Ne}$ retva river mouth and the Bojana/Buna river mouth, and runs further to south Italy, Tunisia and probably also to north African wintering areas in Libya, referred to as South-Adriatic Flyway. Records between the two main routes across the Adriatic Sea indicate lower importance for Spoonbill movements.

The average coordinates of the spring $\left(43.66^{\circ} \mathrm{N}, 15.10^{\circ} \mathrm{E}\right)$ as opposed to their autumn $\left(40.64^{\circ} \mathrm{N}, 13.11^{\circ} \mathrm{E}\right)$ stopover sites are different along the Adriatic Flyway (Figure 6 , 7). The average spring stopover coordinates are closer to the western coast of Balkan Peninsula, while the average autumn coordinates are located closer to the south-western coast of Italy.

We have records from both the autumn and the spring migration periods for eight 


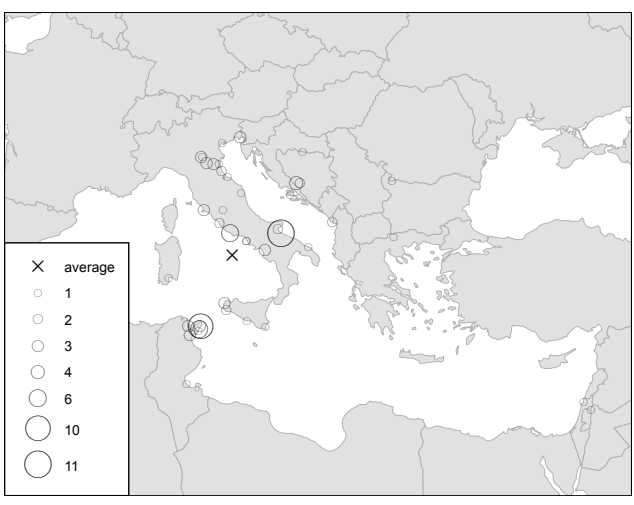

Figure 6. Autumn stopover sites $(1,2,3,4,6$, $10,11)$ of Spoonbills between the Carpathian Basin and the wintering areas. $(x)$ indicates average coordinates of autumn stopover sites. The numbers after the symbols indicate the number of individuals

6. ábra Kanalasgémek őszi megállóhelyei (1, 2, $3,4,6,10,11)$ a Kárpát-medence és a telelőhelyek közt. $A z(x)$ az őszi megállóhelyek átlagkoordinátáit mutatja. A jelölések mellett a számok az egyedszámot jelentik

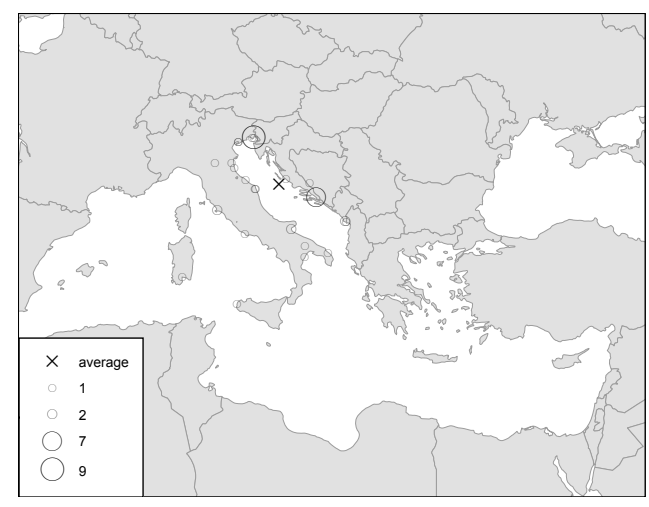

Figure 7. Spring stopover sites (1, 2, 3, 4, 6, 10, 11) of Spoonbills between the Carpathian Basin and the wintering areas. $(x)$ indicates average coordinates of spring stopover sites. The numbers after the symbols indicate the number of individuals

7.ábra Kanalasgémek tavaszi megállóhelyei $(1,2,7,9)$ a Kárpát-medence és a telelőhelyek közt. $A z(x)$ a tavaszi megállóhelyek átlagkoordinátáit mutatja. A jelölések mellett a számok az egyedszámot jelentik

individuals (Figure 8). Five of these birds used stopovers along the same routes: three birds were reported from the North-Adriatic Flyway, while two from the South-Adriatic Flyway. One bird chose the South-Adriatic Flyway and stopped exactly on the same stopover site in the salinas of Ulcinj during its autumn and spring migration. For the last three individuals, it was not possible to determine whether there was a shift between the spring and the autumn migration paths.

Observations from stopover sites in different years were collected for only four individuals, all of them seen during spring migration (Figure 9). Three of them had stopover sites along the same route, and two of them were seen exactly on the same locations, or nearly at the same sites, where they had been observed previously. In the case of the fourth individual, it was not possible to determine if there was a shift between the two spring migration paths from one year to the next.

We analysed 92 records of autumn and 43 records of spring stopover durations along Adriatic Flyway. During autumn migration $(\mathrm{n}=92)$ the average stopover length was $3.6 \pm 0.696$ (mean $\pm \mathrm{SE}$ ) days. The mean length of stay for juveniles $(\mathrm{n}=70)$ was $4.0 \pm 0.856$ (mean $\pm \mathrm{SE}$ ) days, whereas it was $2.6 \pm 1.023$ (mean \pm SE) days for non-juveniles $(1 \mathrm{cy}<, \mathrm{n}=22)$, but the two age groups are statistically not different with respect to stopover length (Mann-Whitney test, $\mathrm{p}=0.520$ ). The detected longest stopover duration was 35 days for juveniles, and 23 days for non-juveniles during the autumn migration. The mean length of spring stopover duration was $2.1 \pm 0.398($ mean \pm SE) days among non-juveniles $(n=43)$. The detected 


\section{Cs. Pigniczki, J. Kralj, S. Volponi, A. Žuljević, M-A. Dakhli, T. Mikuska, H. Azafzaf \& Zs. Végvári}

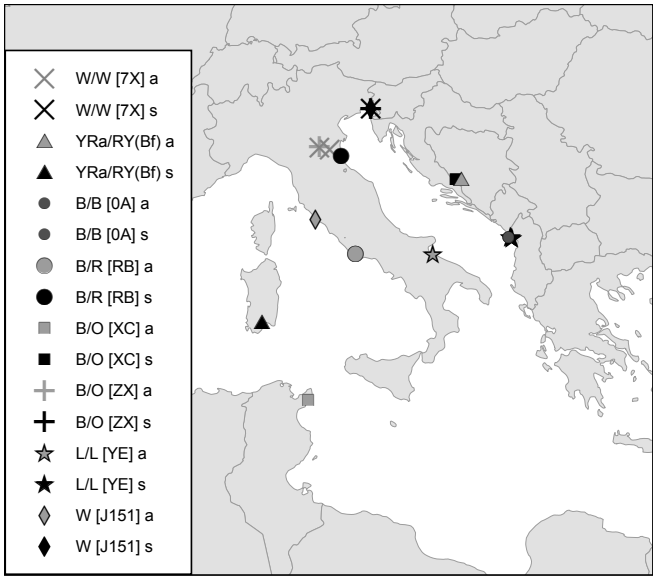

Figure 8. Autumn and spring stopover sites of eight colour marked Spoonbills seen during both autumn and spring migration along the Adriatic Flyway. The letter 'a' after ring code indicates autumn stopover, while the letter ' $s$ ' indicates spring stopover. The North-Adriatic Flyway was used by W/W[7X], B/O[ZX] and W[J151], while the South-Adriatic Flyway was used by $B / B[0 A]$ and $L / L[Y E]$ during both spring and autumn migration. It was not possible to determine whether there was a shift between migration paths in the case of $\mathrm{YRa} / \mathrm{RY}(\mathrm{Bf}), \mathrm{B} / \mathrm{R}[\mathrm{RB}]$ and $\mathrm{B} / \mathrm{O}[\mathrm{XC}]$

8. ábra Nyolc színes gyűrűs kanalasgém őszi és a tavaszi vonulási állomása az adriai vonulási úton. Ezek az egyedek mind az őszi, mind a tavaszi vonulás során megfigyelésre kerültek. Az egyed kódja után $\mathrm{az}$ " $\mathrm{a}^{\prime \prime}$ az őszi, míg a "s" a tavaszi megállóhelyet jelöli. A tavaszi és az őszi vonulás során is az észak-adriai vonulási utat használta a $W / W[7 X]$, a B/O[ZX] és a W[J151] kódú egyed, míg a dél-adriai vonulási úton vonult a $B / B[0 A]$ és a $L / L[Y E]$ kódú példány. $A z Y R a / R Y(B f), a B / R[R B]$ és a $B / O[X C]$ kódú madarak esetén nem dönthető el, hogy tavaszi és őszi vonulásuk alatt az egyik adriai vonulási útról váltottak-e a másikra, vagy ugyanazon vonultak

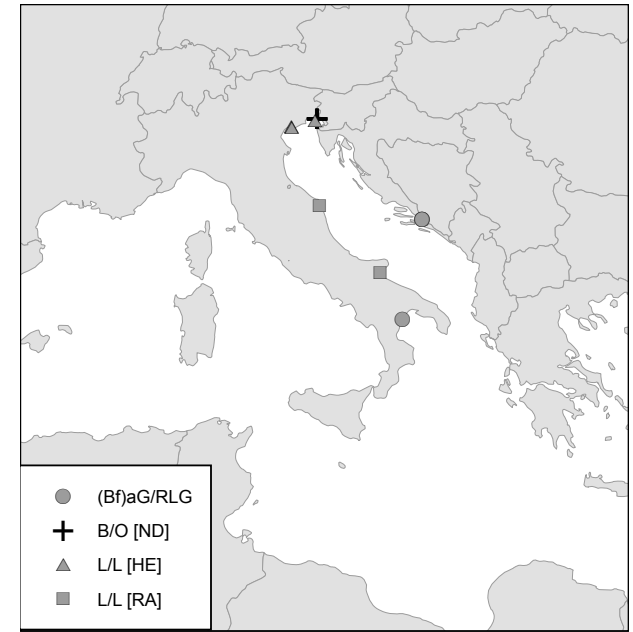

Figure 9. Spring stopover sites of four individuals along the Adriatic Flyway. These individuals were seen in different years during their spring migration. Three individuals were observed along the same migration route where they had been observed previously; (Bf)aG/ RLG stopped in two years along the South-Adriatic Flyway, while B/O[ND] and L/L[HE] stopped along the NorthAdriatic Flyway in two and three years, respectively. It was not possible to determine whether there was a shift between migration paths in the case of L/L[RA]

9. ábra Négy színes gyűrűs kanalasgém tavaszi vonulási állomásai az adriai vonulási úton. Ezek az egyedek legalább két tavaszi vonulás során is megfigyelésre kerültek. Három egyed ugyanazt a vonulási útvonalat használta, mint korábban; a (Bf)aG/RLG kódú egyed két évben állt meg a dél-adriai vonulási úton, míg a $\mathrm{B} / \mathrm{O}[\mathrm{ND}]$ két évben, a $L / L[H E]$ pedig három évben került megfigyelésre az észak-adriai vonulási úton. $A$ L/L[RA] esetén nem dönthető el, hogy a madár váltott-e vonulási utat 


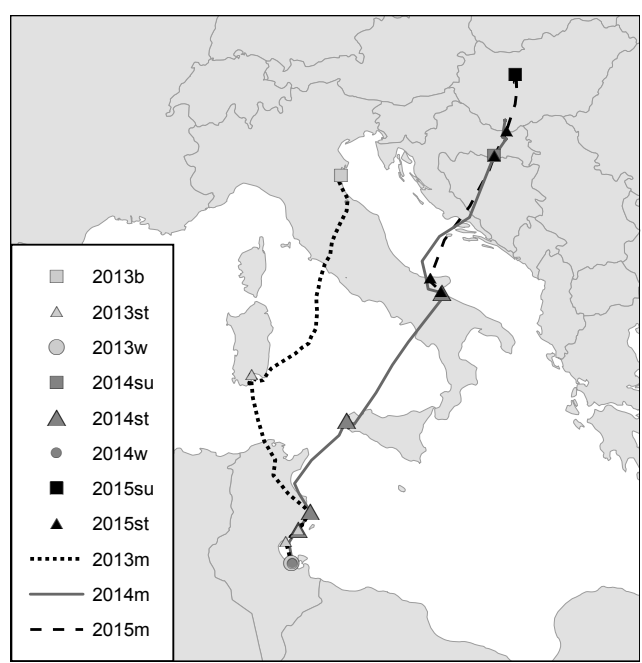

Figure 10. Autumn movements of the GPS tagged individual between the breeding/summering areas and the wintering area. The numbers next to the symbols indicate the year of migration. The meanings of letters after numbers: $b$ - breeding area; st - stopover site; $w$ - wintering area; su - summering area; $\mathrm{m}$ - migration path

10. ábra A jeladós kanalasgém őszi vonulásai a költő-/nyaralóhely és a telelőterület között. A számok a szimbólumok mellett a vonulás évét jelentik. A betǔk jelentése a számok mellett: $b$ - fészkelőhely; st - megállóhely; w - telelőhely; su - átnyaralóhely; m - vonulási út

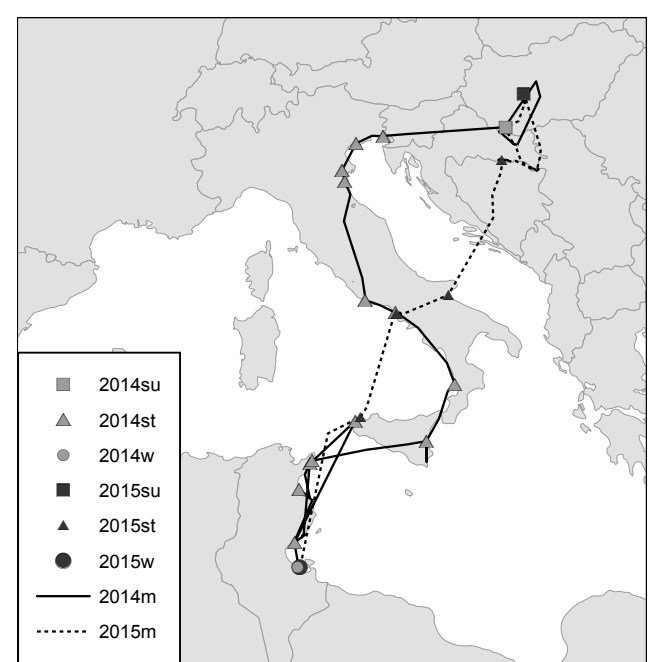

Figure 11. Spring movements of the GPS tagged individual between the wintering area and the breeding/summering areas. The numbers next to the symbols indicate the year of migration. The meanings of letters after numbers: st stopover site; $\mathrm{w}$ - wintering area; su summering area; $\mathrm{m}$ - migration path

11. ábra A jeladós kanalasgém tavaszi vonulásai a telelőhely és a költő-/nyaralóhely között. A számok a szimbólumok mellett a vonulás évét jelentik. A betűk jelentése a számok mellett: st - megállóhely; w - telelőhely; su - átnyaralóhely; $\mathrm{m}$ - vonulási út

longest stopover duration during spring migration was 14 days. The difference between the autumn and spring stopover duration is not significant either between non-juveniles $(1 \mathrm{cy}<)$ (Mann-Whitney test, $\mathrm{p}=0.993$ ) or between all individuals (Mann-Whitney test, $\mathrm{p}=0.487$ ).

A few lucky observations allowed us to derive information on the speed of migration. One juvenile individual was observed in the natal area in Hungary on the $2^{\text {nd }}$ of October, and was next observed on the coast of Djerba Island, Tunisia in the wintering area on $9^{\text {th }}$ of October. The distance between the two sites $(1698 \mathrm{~km})$ was covered by the Spoonbill within seven days, which indicates a minimum speed of $243 \mathrm{~km} /$ day. During spring migration a 5 cy individual was observed at a stopover site in Italy on $26^{\text {th }}$ of April, and was resighted in the breeding area in Serbia on $29^{\text {th }}$ of April. That individual moved 651 kilometres within 3 days, with an average speed of $217 \mathrm{~km} /$ day.

Our database includes records of four individuals, which used two stopover sites within one migration season. The distance between two stopovers was between 70 and $546 \mathrm{~km}$ (Table 1), with no information on any other stops. 


\section{Spoonbill with GPS device}

The adult Spoonbill equipped with a GPS tag provided detailed information on five journeys: three from breeding/summering areas to wintering grounds and two from the return flights, which occurred between late summer of 2013 and the autumn of 2015 (Figure 10, 11, Table 2, 3).

In 2013, southward migration started on $1^{\text {st }}$ of October from the wetlands around Comacchio (Italy), where it bred in that year. After a non-stop flight, it stopped for two weeks in Cagliari in Sardinia, and then continued its journey to Tunisia, to the Gulf of Gabes. The bird spent the winter there, mainly in the coastal, tidal wetlands west of the town of Gourine.

The bird's path at the start of the following spring migration in 2014 was less linear. The Spoonbill flew to Sicily (Trapani saltpans) between $1^{\text {st }}$ and $4^{\text {th }}$ of April but after two days, on $6^{\text {th }}$ of April returned back to the Gulf of Gabes and stayed there for 12.5 days. On $21^{\text {st }}$ of April the Spoonbill moved again and reached wetlands south of Catania in Sicily. It resumed migration on the $3^{\text {rd }}$ of May and the route strictly followed the Tyrrhenian coast to the Lake of Fogliano. After a 40-hour stop the Spoonbill flew to the Comacchio lagoons where it visited the breeding colony, but then moved to rice fields nearby and spent 9.5 days there. The journey continued with a two-day stop at the lagoon of Venice, and a one day long stop in the river mouth of Isonzo and finally finished on the Fishpond Sumony (S Hungary) on $20^{\text {th }}$ of May. It probably did not breed in 2014 because it moved back and forth from wetlands in south and central Hungary to fishponds along the Sava river in Croatia and Bosnia and Herzegovina between its arrival to Hungary and the end of July, never stopping in the same area for more than 10-15 days.

The following autumn, movement towards south started on $13^{\text {rd }}$ of October. The adult Spoonbill departed from Fishpond Jelas (Croatia), and in a single journey crossed the mid-Adriatic Sea south of Split and finally settled in the Gulf of Manfredonia for 11 days. Then it took three more steps with stops in the salinas of Trapani (Sicily) and Chebba (Tunisia) and arrived to the Gulf of Gabes, the same region where it had spent the previous winter.

In the spring 2015, the return migration started on $26^{\text {th }}$ of April, directly from the wintering ground in the Gulf of Gabes. A three-step movement through the wetlands of Campania and Manfredonia (Italy) and across mid-Adriatic Sea finished close to Fishpond Jelas

\begin{tabular}{|l|c|c|c|c|}
\hline Individual & Stopover coordinates 1 & Stopover coordinates 2 & Distance & Elapsed time (day) \\
\hline W/W [3P] & $41.40^{\circ} \mathrm{N} ; 12.88^{\circ} \mathrm{E}$ & $42.43^{\circ} \mathrm{N} ; 11.20^{\circ} \mathrm{E}$ & $181 \mathrm{~km}$ & 5 \\
\hline $\mathrm{B} / \mathrm{L}[\mathrm{YP}]$ & $44.88^{\circ} \mathrm{N} ; 11.07^{\circ} \mathrm{E}$ & $44.57^{\circ} \mathrm{N} ; 11.83^{\circ} \mathrm{E}$ & $70 \mathrm{~km}$ & 26 \\
\hline $\mathrm{W}[\mathrm{J} 240]$ & $41.02^{\circ} \mathrm{N} ; 13.92^{\circ} \mathrm{E}$ & $40.72^{\circ} \mathrm{N} ; 17.80^{\circ} \mathrm{E}$ & $328 \mathrm{~km}$ & 9 \\
\hline $\mathrm{W}[\mathrm{J} 224]$ & $40.57^{\circ} \mathrm{N} ; 15.07^{\circ} \mathrm{E}$ & $36.83^{\circ} \mathrm{N} ; 10.98^{\circ} \mathrm{E}$ & $546 \mathrm{~km}$ & 36 \\
\hline
\end{tabular}

Table 1. Coordinates of stopover sites of four individuals found on two stopovers during the same autumn migration and the distance between the stopover sites and the time between the observations. See also Figure 1.

1. táblázat Az őszi vonulás során két megállóhelyen is megfigyelt négy példány megállóhelyeinek koordinátái, valamint a megállóhelyek távolsága és a megfigyelések között eltelt idő. Lásd az 1. ábrát is 


\begin{tabular}{|c|c|c|c|c|c|c|}
\hline $\begin{array}{l}\text { Migration } \\
\text { season, year }\end{array}$ & $\begin{array}{l}\text { Time and date } \\
\text { of departure }\end{array}$ & Location of departure & $\begin{array}{l}\text { Time and date } \\
\text { of arrival }\end{array}$ & $\begin{array}{l}\text { Location of } \\
\text { arrival }\end{array}$ & $\begin{array}{c}\text { Distance } \\
\text { between } \\
\text { stops }(\mathbf{k m})\end{array}$ & $\begin{array}{c}\text { Time (hour) } \\
\text { between stops }\end{array}$ \\
\hline A 2013 & \begin{tabular}{|l}
$6: 00-6: 30,1$ \\
October \\
\end{tabular} & Valli di Comacchio (I) & $\begin{array}{l}\text { 21:30-22:00, } 1 \\
\text { October }\end{array}$ & Cagliari (I) & 755 & $17-18$ \\
\hline A 2013 & $\begin{array}{l}\text { 20:00-21:00, } 16 \\
\text { October }\end{array}$ & Cagliari (I) & $\begin{array}{l}\text { 6:00-7:00, } 17 \\
\text { October }\end{array}$ & Sidi Mansour (To) & 536 & $9-11$ \\
\hline A 2013 & $\begin{array}{l}\text { 12:00-18:00, } 17 \\
\text { October }\end{array}$ & Sidi Mansour (To) & $<24: 00,17$ October & Kneiss Island (To) & 78 & $6-12$ \\
\hline A 2013 & $>0: 00,20$ October & Kneiss Island (To) & $<12: 00,20$ October & Gourine (To) & 78 & $<12$ \\
\hline S 2014 & 1 April & Gourine (To) & 1 April & Kneiss Island (To) & 78 & \\
\hline S 2014 & 6:00-12:00, 2 April & Kneiss Island (To) & $<18: 00,2$ April & $\begin{array}{l}\text { Sebkhet Halk el } \\
\text { Manzel (To) } \\
\end{array}$ & 212 & $6-12$ \\
\hline S 2014 & $\begin{array}{l}\text { 00:00-12:00, } 3 \\
\text { April }\end{array}$ & $\begin{array}{l}\text { Sebkhet Halk el Manzel } \\
\text { (To) }\end{array}$ & 12:00-18:00, 3 April & $\begin{array}{l}\text { Barrage Lebna } \\
\text { (To) }\end{array}$ & 95 & $6-12$ \\
\hline S 2014 & $>6: 00,4$ April & Barrage Lebna (To) & $<18: 00,4$ April & $\begin{array}{l}\text { Trapani saltpans } \\
\text { (I) }\end{array}$ & 203 & $<12$ \\
\hline S 2014 & $>6: 00,6$ April & Trapani saltpans (I) & $<24: 00,6$ April & Kneiss Island (To) & 428 & $<18$ \\
\hline S 2014 & $>6: 00,19$ April & Sfax (To) & $<18: 00,19$ April & $\begin{array}{l}\text { Barrage Lebna } \\
\text { (To) }\end{array}$ & 240 & $<12$ \\
\hline S 2014 & $>6: 00,21$ April & Sidi Abdel Monaam (To) & $<24: 00,21$ April & $\begin{array}{l}\text { Mouth River } \\
\text { Simeto, Catania (I) }\end{array}$ & 370 & $<18$ \\
\hline S 2014 & 8:00-12:00, 3 May & S of Catania (I) & 14:00-16:00, 3 May & $\begin{array}{l}\text { Mouth River } \\
\text { Savuto (I) }\end{array}$ & 204 & $2-8$ \\
\hline S 2014 & 2:00-4:00, 4 May & Mouth River Savuto (I) & 14:00-16:00, 4 May & $\begin{array}{l}\text { Mouth River } \\
\text { Volturno (I) }\end{array}$ & 297 & $10-14$ \\
\hline S 2014 & 4:00-6:00, 5 May & Mouth River Volturno (I) & 6:00-14:00, 5 May & Sabaudia (I) & 99 & $<10$ \\
\hline S 2014 & $>6: 00,7$ May & Sabaudia (I) & 18:00-20:00, 7 May & $\begin{array}{l}\text { Comacchio } \\
\text { lagoons (I) }\end{array}$ & 368 & $12-14$ \\
\hline S 2014 & $\begin{array}{l}\text { 6:00-10:00, } 17 \\
\text { May }\end{array}$ & Codigoro rice fields (I) & $<18: 00,17$ May & $\begin{array}{l}\text { Lagoon of Venice } \\
\text { (I) }\end{array}$ & 85 & $8-12$ \\
\hline S 2014 & 2:00-4:00, 19 May & Lagoon of Venice (I) & 8:00-14:00, 19 May & $\begin{array}{l}\text { Mouth of river } \\
\text { Isonzo (I) }\end{array}$ & 80 & $4-12$ \\
\hline S 2014 & $\begin{array}{l}>6: 45-10: 00,20 \\
\text { May }\end{array}$ & Mouth of river Isonzo (I) & $<20: 00,20$ May & $\begin{array}{l}\text { Fishpond } \\
\text { Sumony }(H)\end{array}$ & 340 & $10-13$ \\
\hline A 2014 & $>8: 00,13$ October & Fishpond Jelas (Hr) & $<24: 00,13$ October & Manfredonia (I) & 515 & 16 \\
\hline A 2014 & $\begin{array}{l}: 00-12: 00,27 \\
\text { October }\end{array}$ & Manfredonia (I) & $\begin{array}{l}\text { 18:00-20:00, } 27 \\
\text { October }\end{array}$ & Trapani (I) & 519 & $6-12$ \\
\hline A 2014 & $\begin{array}{l}\text { 18:00-20:00, } 2 \\
\text { November }\end{array}$ & Trapani (I) & $\begin{array}{l}\text { 6:00-8:00, } 3 \\
\text { November }\end{array}$ & Chebba (To) & 372 & $10-12$ \\
\hline A 2014 & $\begin{array}{l}>22: 00,3 \\
\text { November }\end{array}$ & Chebba (To) & $\begin{array}{l}<24: 00,3 \\
\text { November }\end{array}$ & Sfax (To) & 51 & $<2$ \\
\hline A 2014 & $\begin{array}{l}>18: 00,8 \\
\text { November }\end{array}$ & Sfax (To) & $\begin{array}{l}\text { 20:00-22:00, } 8 \\
\text { November }\end{array}$ & Gourine (To) & 108 & $2-4$ \\
\hline S 2015 & $>6: 00,26$ April & Gourine (To) & $<24: 00,26$ April & NW Sicily (I) & 567 & 18 \\
\hline S 2015 & $\begin{array}{l}00: 00-6: 00,27 \\
\text { April }\end{array}$ & NW Sicily (I) & $<18: 00,27$ April & $\begin{array}{l}\text { Mouth river } \\
\text { Volturno (I) } \\
\end{array}$ & 342 & $12-18$ \\
\hline S2015 & 6:00-8:00, 7 May & Mouth river Volturno (I) & $<16: 00,7$ May & Manfredonia (I) & 162 & $8-10$ \\
\hline S 2015 & $>$ 8:00, 9 May & Manfredonia (I) & 18:00-20:00, 9 May & $\begin{array}{l}\text { Fishpond Jelas } \\
(\mathrm{Hr})\end{array}$ & 435 & $10-12$ \\
\hline A 2015 & $\begin{array}{l}\text { 9:00-12:00, } 15 \\
\text { October }\end{array}$ & Rétszilas (H) & $<15: 00,15$ October & $\begin{array}{l}\text { Donji Miholiac } \\
(\mathrm{Hr})\end{array}$ & 122 & $3-6$ \\
\hline A 2015 & $\begin{array}{l}>9: 00,22 \\
\text { October }\end{array}$ & Donji Miholiac (Hr) & $<18: 00,22$ October & $\begin{array}{l}\text { Fishpond Jelas } \\
(\mathrm{Hr})\end{array}$ & 78 & 9 \\
\hline A 2015 & $>6: 00,30$ October & Fishpond Jelas (Hr) & $<21: 00,30$ October & $\begin{array}{l}\text { Lakes of } \\
\text { Lesina-Varano (I) }\end{array}$ & 408 & 15 \\
\hline A 2015 & $\begin{array}{l}>12: 00,31 \\
\text { October }\end{array}$ & $\begin{array}{l}\text { Lakes of Lesina-Varano } \\
\text { (I) }\end{array}$ & $<24: 00$ October 31 & Manfredonia & 59 & $<12$ \\
\hline
\end{tabular}

Table 2. Migration pattern of the Spoonbill with GPS device. "A" means autumn migration, "S" means spring migration. Distance between two stops was calculated based on the signals of the GPS device

2. táblázat $A$ jeladós kanalasgém vonulási mintázata. $A z_{\text {„ }} \mathrm{A}^{\prime}$ az őszi, míg a "S" a tavaszi vonulást jelenti. $A$ távolságot két megállás között a jeladó adatai alapján számítottuk 


\begin{tabular}{|c|c|c|c|c|}
\hline $\begin{array}{c}\text { Migartion } \\
\text { season, year }\end{array}$ & Stopover site & $\begin{array}{c}\text { Arrival to } \\
\text { stopover site }\end{array}$ & $\begin{array}{l}\text { Departure from } \\
\text { stopover site }\end{array}$ & $\begin{array}{l}\text { Duration of stay at } \\
\text { stopover site (days) }\end{array}$ \\
\hline A 2013 & Cagliari (I) & $\begin{array}{l}\text { 21:30-22:00, } 1 \\
\text { October }\end{array}$ & $\begin{array}{l}\text { 20:00-21:00, } 16 \\
\text { October }\end{array}$ & 15 \\
\hline A 2013 & Sidi Mansour & $\begin{array}{l}\text { 6:00-7:00, } 17 \\
\text { October }\end{array}$ & $\begin{array}{l}\text { 12:00-18:00, } 17 \\
\text { October }\end{array}$ & $0.2-0.5$ \\
\hline A 2013 & Kneiss Island (To) & $\begin{array}{l}\text { 18:00-24:00, } 17 \\
\text { October }\end{array}$ & $\begin{array}{l}\text { 00:00-6:00, } 20 \\
\text { October }\end{array}$ & $2-2.5$ \\
\hline S 2014 & Kneiss Island (To) & 1 April & 2 April & \\
\hline S 2014 & $\begin{array}{l}\text { Sebkhet Halk el } \\
\text { Manzel (To) }\end{array}$ & $\begin{array}{l}\text { 12:00-18:00, } 2 \\
\text { April }\end{array}$ & 00:00-6:00, 3 April & $0.5-0.75$ \\
\hline S 2014 & Trapani saltpans (I) & 18:00, 4 April & 6:00, 6 April & 1.5 \\
\hline S 2014 & $\begin{array}{l}\text { Kneiss Island - Sfax } \\
\text { (To) }\end{array}$ & 00:00, 7 April & 6:00-12:00, 19 April & 12.5 \\
\hline S 2014 & $\begin{array}{l}\text { Barrage Lebna / Sidi } \\
\text { Abdel Monaam }\end{array}$ & $\begin{array}{l}\text { 6:00-18:00, } 19 \\
\text { April }\end{array}$ & 6:00-12:00, 21 April & 2 \\
\hline S 2014 & $\begin{array}{l}\text { Wetlands S of } \\
\text { Catania }\end{array}$ & $\begin{array}{l}\text { 18:00-24:00, } 21 \\
\text { April }\end{array}$ & 8:00-10:00, 3 May & 11.5 \\
\hline S 2014 & $\begin{array}{l}\text { Mouth river Savuto } \\
\text { (I) }\end{array}$ & 15:00-16:00, 3 May & 2:00-4:00, 4 May & 0.5 \\
\hline S 2014 & $\begin{array}{l}\text { Mouth river Volturno } \\
\text { (I) }\end{array}$ & 12:00-14:00, 4 May & 4:00-6:00, 5 May & 0.5 \\
\hline S 2014 & Sabaudia (I) & 6:00-14:00, 5 May & $>6: 00,7$ May & 2 \\
\hline S 2014 & $\begin{array}{l}\text { Rice fields near } \\
\text { Comacchio lagoons } \\
\text { and Codigoro (I) }\end{array}$ & 18:00-20:00, 7 May & 6:00-10:00, 17 May & 9.5 \\
\hline S 2014 & Lagoon of Venice (I) & $<18: 00,17$ May & 2:00-4:00, 19 May & 1.5 \\
\hline S 2014 & Mouth river Isonzo (I) & 8:00-14:00, 19 May & $>$ 6:45-10:00, 20 May & 0.75 \\
\hline A 2014 & Manfredonia (I) & $\begin{array}{l}<24: 00,13 \\
\text { October }\end{array}$ & $\begin{array}{l}\text { 8:00-12:00, } 27 \\
\text { October }\end{array}$ & 13.5 \\
\hline A 2014 & Trapani (I) & $\begin{array}{l}\text { 18:00-20:00, } 27 \\
\text { October }\end{array}$ & $\begin{array}{l}\text { 18:00-20:00, } 2 \\
\text { November }\end{array}$ & 6 \\
\hline A 2014 & Chebba(To) & 8:00, 3 November & $\begin{array}{l}\text { 22:00-24:00, } 3 \\
\text { November }\end{array}$ & $0.5-0.75$ \\
\hline A 2014 & Sfax (To) & 00:00, 4 November & $\begin{array}{l}\text { 16:00-18:00, } 8 \\
\text { November }\end{array}$ & 4.75 \\
\hline S 2015 & NW Sicily (I) & $<24: 00,26$ April & 00:00-6:00, 27 April & 0.25 \\
\hline S 2015 & $\begin{array}{l}\text { Mouth river Volturno } \\
\text { (I) }\end{array}$ & $<18: 00,27$ April & 6:00-8:00, 7 May & 9.5 \\
\hline S 2015 & Manfredonia (I) & $<16: 00,7$ May & $>$ 8:00, 9 May & 1.75 \\
\hline A 2015 & Donji Miholiac (Hr) & $\begin{array}{l}<15: 00,15 \\
\text { October }\end{array}$ & $>$ 9:00, 22 October & 6.75 \\
\hline A 2015 & Fishpond Jelas (Hr) & $\begin{array}{l}<18: 00,22 \\
\text { October }\end{array}$ & $>6: 00,30$ October & 7.5 \\
\hline A 2015 & $\begin{array}{l}\text { Lakes of } \\
\text { Lesina-Varano (I) }\end{array}$ & $\begin{array}{l}<21: 00,30 \\
\text { October }\end{array}$ & $>12: 00,31$ October & 0.63 \\
\hline
\end{tabular}

Table 3. Arrival and departure date and stopover duration of Spoonbill with GPS device during migration. "A" means autumn migration, " $\mathrm{S}$ " means spring migration.

3. táblázat $A$ jeladós kanalasgém érkezése és elvonulása az egyes megállóhelyeken, illetve a rajtuk töltött idő. $A z_{\text {„I }} \mathrm{A}^{\prime \prime}$ az őszi, míg a "S" a tavaszi vonulást jelképezi 
(Croatia) on $9^{\text {th }}$ of May. The Spoonbill spent the following summer moving among wetlands located in central Hungary or along the Danube and the Sava rivers and, likely, again skipped breeding.

In 2015, autumn migration started on $15^{\text {th }}$ of October from Fishpond Rétszilas in central Hungary. After a two-step movement to Fishpond Jelas, the Spoonbill made another long flight across mid-Adriatic to coastal lakes of Lesina and Varano and finished its journey on $1^{\text {st }}$ of November in Manfredonia. Data collected in the following days contained a series of points concentrated in an arable field suggesting that the bird died. We suppose it was shot dead by poachers.

The distances of flights between two stopovers were $283.0 \pm 67.3 \mathrm{~km}$ (SE) during autumn migration, and $255.8 \pm 34.3 \mathrm{~km}$ (SE) during spring migration. Stopover duration was $5.7 \pm 1.0$ (SE) days during autumn migration and $3.9 \pm 1.2(\mathrm{SE})$ days during spring migration. The calculated maximal speed of flight was between $48.7-59.6 \mathrm{~km} / \mathrm{h}$.

\section{Discussion}

Our resight records indicate that Spoonbills from Central Europe mainly use the Central Mediterranean or the Adriatic part of the Black Sea/Mediterranean Flyway. Waterbirds (including Spoonbills) may fly along the Adriatic coast and they can also cross the Adriatic Sea (Sackl et al. 2014). Kralj et al. (2012) reported Spoonbills crossing the central part of the Adriatic Sea. Smart et al. (2007) supposed that Spoonbills cross the Adriatic Sea at the Straight of Otranto, but we did not find evidence for that. Our results from colour-ringed birds indicate that high number of Spoonbills may cross the Adriatic Sea between Gulf of Manfredonia (Italy) and (1) Ulcinj (Montenegro), or (2) the coastline among Split and Metković (Croatia). GPS tracks of the adult Spoonbill also support this hypothesis. Resights also confirm that individuals breeding/summering in the Carpathian basin or NE Italy may fly along the west Adriatic coast before crossing the Appenines, stop in coastal wetlands of central Italy before flying to the wintering grounds in Tunisia. Alternatively, North Africa can be reached both via Sicily or Sardinia. The same routes can be used during spring migration. A few Spoonbills were reported from the East Mediterranean area, where West Asian/ East African and Black Sea/Mediterranean Flyways overlap while a few birds were detected along East Atlantic coast, where the East Atlantic and Black Sea/Mediterranean Flyways overlap.

We have identified two routes used by Spoonbills within the Adriatic Flyway, the North-Adriatic and the South-Adriatic Flyways. We suppose that these routes are defined by suitable wetlands, as the North Adriatic Flyway includes wetlands in north-eastern Italy and follows mainly the north Adriatic coast and as far as we know does not cross the Adriatic Sea. In contrast, the South-Adriatic Flyway involves wetlands across the western Balkan Peninsula (the karst lakes of Bosnia and Herzegovina and coastal wetlands between Split and northern Albania) and crosses the Adriatic Sea. Between those two routes there are few or no wetlands suitable for Spoonbills as resting or refuelling sites both along the Adriatic coasts of the Balkans and Italy. This is also confirmed by field observations that report 
only small number of Spoonbills from the intermediate coastal Croatian areas (Stumberger et al. 2013), as there are only a few wetlands appropriate for this species. Similarly, the Italian coast between Cervia and Lesina is hilly and highly anthropized without wetlands suitable for waterbirds. GPS tracks suggest that the two Adriatic routes may overlap in S Italy and join between W Sicily and Cape Bon where birds chose to address towards the wintering grounds located along the West or South coast of Tunisia. Our results imply that most individuals may use stopover sites along the same migration route (North- or South-Adriatic Flyway) during both spring and autumn migrations. Furthermore, most Spoonbills showed high fidelity to the same stopover sites or areas in their vicinity in following years, although we also detected in a single occasion (in the case of adult fitted with GPS) where Spoonbill shifted from the North-Adriatic Flyway to the South-Adriatic one. The bulk of our observations indicate fidelity to stopover sites during both migrations, but further studies are needed because of the small available sample size.

We have identified 59 stopover sites in the Balkan Peninsula, Italy, the Middle East and North Africa by the resights of colour ringed Spoonbills ringed in Central Europe and another four by the signal of the GPS device. We believe that we were able to delineate the most important stopovers along the Adriatic Flyway using these methods. However, there could be further important stopover sites in Albania and western Greece, from where observations are lacking, and probably we were not able to recognise several stopovers in North-Africa after birds left Cape Bon or Lake Tunis in Tunisia. The GPS-tagged Spoonbill's track revealed that birds may stop at additional sites along the northern and eastern coast of Tunisia but preferably move to the more suitable tidal areas located in the Gulf of Gabes which are largely used in winter (Smart et al. 2007). Interestingly, two stopover sites were also found in the Carpathian Basin by tracking the Spoonbill with the GPS tag. Stopover sites of Spoonbills from Central Europe were previously identified only in the west Balkan Peninsula (Slovenia, Croatia, Bosnia and Herzegovina, Montenegro, northwest Albania) (Stumberger et al. 2013). As most of the Central European Spoonbills migrate to Tunisia and Italy (Smart et al. 2007, Pigniczki 2009, 2010, Kralj et al. 2012, Pigniczki \& Karcza 2013), this study covered large part of the most important stopover sites for this population along the Adriatic Flyway. The estimated number of wintering individuals in Tunisia is high; between 3447 and 4033 individuals were counted by January IWC between 2008 and 2014 (Azafzaf et al. 2015). In Italy, the number of wintering Spoonbills recorded by mid-January IWC, increased from less than 100 individuals distributed across eight sites in 1991-1995, to almost 800 individuals spread over 44 sites in 2006-2010 (Zenatello et al. 2014).

We have only few records of stopovers from the central and eastern part of the Balkan Peninsula, and we have only limited numbers of records from the Middle East. These sites seems to belong to another route used by Spoonbills, with known wintering areas in Turkey and mainly old winter recoveries along the Egyptian and Sudanese part of the Nile (Pigniczki 2009, 2010, Pigniczki \& Karcza 2013). However, the East-Mediterranean area is not the main migratory and wintering area for the Central European population: those sites are mainly used by Eastern European Spoonbills as a large proportion of individuals ringed in the Danube Delta (Romania) were observed in Israel and also in Turkey, Cyprus and Oman 
(Kiss et al. 2007). Israel is an important area both during autumn migration, with up to 900 individuals observed, and as a wintering site hosting around 800-1500 individuals in north of the country (Shirihai et al. 1996). Furthermore, flocks of up to 70 individuals were seen in Egypt during migration in the 1980s, with no wintering records from the Nile Delta from the same period (Goodman \& Meininger 1989); however, no recent records are available in the literature from this location. Wintering Spoonbills (including a Serbian ringed individual) were observed in 2008-2015 along the Nile at Abu Simbel (maximum of 11 individuals) and at Aswan (maximum of 40 individuals) (D. Hoek \& H. Ibrahim pers. comm.). As there is only a small overlap between the flyways of Central European and East European Spoonbills (Kiss et al. 2007, Kralj et al. 2012, Pigniczki 2015) our results support the proposal of splitting the Central and the East European Spoonbill populations, which have been considered to belong to the same population in the recent international action plan of the species (Triplet et al. 2008). This would help to best address future conservation actions (Pigniczki et al. in press).

Staging areas of trans-Saharan migrants remained completely unknown. Spoonbills from the Carpathian Basin and NE Italy reach wetlands in Niger, Nigeria and Mali (Spina \& Volponi 2008, Volponi et al. 2008, Pigniczki 2009, 2010, Kralj et al. 2012, Pigniczki \& Karcza 2013). We suppose that trans-Saharan migrants may have staging areas in the coastal wetlands of Gulf of Gabes and stopover sites in desert wetlands of Tunisia and Algeria. Trans-Saharan migration is a risky journey, as several individuals with Carpathian Basin origin were found dead in the middle of the desert in Algeria (Pigniczki \& Karcza 2013). Recent observations indicate that only small numbers of Spoonbills are found in the wetlands of the Sahel (Triplet et al. 2008, Zwarts et al. 2009, J. Broower pers. comm.).

Some colour-ringed individuals reached the Atlantic coast of Africa and spent the winter in Morocco and Mauritania (Pigniczki \& Karcza 2013). However, we have only limited numbers of observations of Central European individuals from this route, thus this wintering area seems to be only marginally important for this population. However, West African sites are essential wintering areas of the Spanish and Dutch populations (de le Court \& Aguilera 1997, Lok et al. 2011). Central European Spoonbills may reach the east Atlantic coast after flying along the coast of the Mediterranean Sea.

From earlier recoveries of metal-ringed individuals we know that Spoonbills used stopover sites along the coasts of Italy and Montenegro, the karst lakes of Bosnia and Herzegovina, wetlands along the River Danube in southern Romania, and further away in Camargue (France) and the European part of Turkey (Pigniczki 2010). These data complement recent records of colour-ringed birds, in the sense that Spoonbills also used the eastern part of the Balkans in the past, and reached the coastal Mediterranean Sea west of Italy. Spoonbills probably still use these sites in low numbers, but we suspect the observation effort is low in the Balkan Peninsula, and this resulted in few records from these sites (Pigniczki \& Végvári 2015).

Certain stopover sites were used more often in spring while others were preferred in autumn along the Adriatic Flyway: for example, wetlands in the Po Delta, Margherita di Savoia saltpans and water reservoirs of Cape Bon were used dominantly during autumn, while the delta of Neretva River and the mouth of the River Isonzo (NE Italy) were used mainly 
during spring migration. Different autumn and spring migration strategies may result in differential preferences for stopover sites in autumn and spring. This pattern could be also a result of observational bias, as it could be difficult to detect Spoonbills during the short time of spring stopovers in Tunisia or in southern Italy, where also transient and wintering birds may mix. The track of the Spoonbill with the GPS tag indicates that birds may also use the water reservoirs of Cape Bon during spring migration. Further, the Delta of Neretva River is not used during autumn migration because human disturbance is heavier that time than in spring (Stumberger et al. 2013, Pigniczki et al. in press).

We also found that: (1) stopover duration may last longer for juveniles than for non-juveniles $(<1 \mathrm{cy})$, and (2) Spoonbills may have longer stopover duration during autumn than spring migration. However, we did not find statistical support for these results. Juveniles generally stay longer on stopover sites than adults, as it could be expected because 1cy are unexperienced individuals (Nilsson et al. 2013). Furthermore, adults during spring migration have generally shorter stopover duration than on autumn migration, as they try to arrive back to the breeding areas as fast as it is possible to occupy the best territories to breed (Nilsson et al. 2013).

Interestingly, the average autumn stopover duration of Spoonbills seems to be longer along the Adriatic Flyway than in the north Iberian stopover site on the East Atlantic Flyway, which site is mostly used by long-distance migrants (Navedo et al. 2010, Kralj et al. 2012). Those individuals of the East Atlantic population which cross the Sahara spend on average 2.7 days at stopovers, while Spoonbills wintering in South-Iberia spend 1.5 days there (Navedo et al. 2010). These stopover durations seem to be different from that of Spoonbills from the Central European population, which indicate that the two populations may have different migration and stopover strategies. However, further studies are needed to confirm our result of longer stopovers along the Adriatic Flyway.

Distances between stopover sites used by the same individual within one season were between 70 and $546 \mathrm{~km}$, and the bird with GPS device showed similar distances (between 78 and $755 \mathrm{~km}$ ). This indicates that Spoonbills that use the Adriatic Flyway may employ hopping or skipping migration strategy (Warnock 2010), but our sample size is very small. As several stopover sites are found halfway between the natal or breeding area located in the Carpathian Basin and the wintering area in southern Italy or northern Africa, this also supports the assumption that most of the Central European Spoonbills belong to hoppers or skippers. However, a small number of Central European Spoonbills that cross the Sahara (Smart et al. 2007, Kralj et al. 2012, Pigniczki \& Karcza 2013), may belong to jumpers during their trans-Saharan migration (Warnock 2010).

Data provided by the Spoonbill fitted with the GPS device showed that migration could be both diurnal and nocturnal. Cramp and Simmons (1977) described the migration of Spoonbills as a mainly diurnal activity. Our focal individual spent up to 17-18 hours in the air between two stops with active flights. The bird retreated after departing during its spring migration in 2014 and returned to the Gulf of Gabes. After a long stay in the wintering area, it eventually reached its previous breeding site in Italy, then later moved to the Carpathian Basin. The reason of the unusual spring retreat to the wintering site remained unknown. On those days no extreme weather conditions were recorded, but on the $5^{\text {th }}$ and $6^{\text {th }}$ of April 
winds turned from W to NW blowing with speed of 7.6 to $44.6 \mathrm{~km} / \mathrm{h}$ (data source: https:// weatherspark.com). Similarly, that individual arrived to the Carpathian Basin also very late in 2015. Birds may reverse their heading and retreat during migration if encounter harsh or extreme weather events (Strandberg et al. 2009). If migrants start their spring migration too late or retreat during the course of the journey, they are likely arrive later at their breeding area, and either skip breeding or if they breed, generally have low breeding success (carry over effect) (Strandberg et al. 2009, Zwarts et al. 2009, Lok 2013). The state of wetlands in the breeding area may also have a significant influence on the decision to whether or not start to breed. For instance, adult Spoonbills in the Carpathian Basin may skip breeding under dry conditions (Pigniczki 2015, Pigniczki \& Végvári 2015). We suspect the adult bird with GPS device was shot dead in Italy, as the same happened to two out of three young that started to winter in this area. Poaching pressure is high along Adriatic Flyway, especially on the Balkans (Schneider-Jacoby 2008).

Our results highlight the importance of the Adriatic Flyway for Spoonbills. Similarly, most waterbird species breeding in Central Europe also use the Adriatic Flyway (Schneider-Jacoby 2008). The wintering areas of waterbird species using the Adriatic Flyway are mostly located in North Africa, with large concentrations of wintering individuals in the Gulf of Gabes (Tunisia and Libya) and in the Niger Basin (Schneider-Jacoby 2008). Migratory bird censuses indicate the special importance of the Adriatic Flyway for ducks at Bojana-Buna river delta, as thousands of Garganeys (Anas querquedula), Northern Shovelers (Anas clypeata) and Eurasian Wigeons (Anas penelope) were seen during their migration over the Adriatic Sea (Sackl et al. 2014). Furthermore, the Adriatic Flyway has special importance for the Common Crane (Grus grus) as well. Large numbers of Cranes use the two main routes of the Adriatic Flyway (North and South), similarly to what we described here for Spoonbills (Stumberger \& Schneider-Jacoby 2010).

Stopover sites have key importance during migration (Navedo et al. 2010b, Warnock 2010), so we believe that our results are useful for Spoonbill and wetland conservation projects along the Adriatic Flyway. The AEWA Single Species Action Plan for the Eurasian Spoonbill provides limited information on migration routes and has no description of stopover sites for the Central European population (Triplet et al. 2008). Our study aims to fill this gap. Assuring habitat and bird protection at stopover sites is of crucial importance, especially in the Balkan Peninsula, where several wetlands have been destroyed or exposed to unsustainable levels of hunting or poaching pressure (Schneider-Jacoby 2008, Stumberger et al. 2013, Pigniczki et al. in press). Furthermore, it is important to identify major migration routes to prevent the establishment of wind farms along the important routes and in the vicinity of key sites, as collision with wind turbines is often fatal for birds (Desholm \& Kahlert 2005, Kirby et al. 2008).

Combining regular surveys of Spoonbills with colour ring readings is an important method to determine which stopovers are used, and which migration routes connect these stopovers among the Central European breeders. As we have only limited numbers of recoveries and there are no continuous data on individual movements, new technologies such as GPSGSM or GPS-GSM-UHF trackers could greatly help to understand movements of birds and integrate that information with traditional survey data (Pigniczki et al. in press). As shown 
by the information gathered by one of the adult Spoonbills equipped with GPS-GSM device in Italy, the use of GPS trackers would allow us to answer open questions, such as the existence of a proposed link between the Balkans and east Libya across the Mediterranean Sea for Spoonbills, which connection has been found for the Montagu's Harrier (Circus pygargus), the Saker Falcon (Falco cherrug) and the Red-footed Falcon (Falco vespertinus) (Palatitz et al. 2009, Zwarts et al. 2009, Prommer et al. 2012, Pigniczki 2015). Furthermore, the connections between colonies of Spoonbills in the Carpathian Basin and wintering sites through the trans-Saharan and the East Mediterranean routes are not known well enough. The need to deploy GPS-trackers on Spoonbills, particularly on individuals breeding in the Carpathian Basin is thus high as the species has a large conservation importance along the Adriatic Flyway (Schneider-Jacoby 2008, Pigniczki et al. in press).

\section{Acknowledgements}

We dedicate this paper to the memory of our Libyan friend, Wagih Bashimam (19632015), who was the first president of Libyan Bird Society and was a keen and helpful team-worker during Spoonbill observations. We are grateful to Zsolt Karcza, head of Hungarian Bird Ringing Center, for co-operating in data management, to Kiskunság National Park Directorate, to Hortobágy National Park Directorate, to BirdLife Hungary and to Otto Overdijk for providing us colour rings. Lorenzo Serra, Alessandro Andreotti and Riccardo Nardelli from ISPRA were part of the team involved in catching and marking the adult Spoonbill followed by the GPS tracker. We thank all observers, especially Habib Dlensi, Michael Smart, Naoufel Hammouda, Foued Hamza, Mohamed Omar El Gouli, Ali Berbash, Khaled Etayeb, Essam Bouras, Mirko Šarac, Dražen Kotrošan, Bariša Ilić, Borut Stumberger, Pierrefrancesco Micheloni and Adriano Talamelli for observations of birds and data management. The Niger Bird DataBase (www.nibdab.org) was kindly provided by Ulf Liedén and Joost Brouwer. We are grateful to Dick Hoek and Haitam Ibrahim for providing his observations from Egypt. We are grateful to Birding Tunisia company and to the Association "Les Amis des Oiseaux" (BirdLife Tunisia) for logistical and financial support during winter counts and ring readings in Tunisia. Csaba Pigniczki is grateful to Peter Sackl for the survey of wetlands in west Balkan and to EuroNatur for the financial support provided for this survey. We finally thank Tibor Csörgö, Szabolcs Lengyel, Andrea Harnos and the two anonymous reviewers for their valuable comments on the early version of the paper. The Hungarian Bird Ringing Centre was supported by the Ministry of Agriculture. The Italian Ministry for the Environment (MATTM) funded the GPS-GSM tracker used on the adult Spoonbill. 


\section{References}

Alerstam, T. 2001. Detours in bird migration. - Journal of Theoretical Biology 209(3): 319-331. DOI: 10.1006/jtbi.2001.2266

Alerstam, T., Hedenström, A. \& Akesson, S. 2003. Long-distance migration: evolution and determinants. - Oikos 103(2): 247-260. DOI: 10.1034/j.1600-0706.2003.12559.x

Azafzaf, H., Feltrup-Azafzaf, C., Dlensi, H. \& Isenmann, P. 2015. Nouvelles données sur l'avifaune de Tunisie (2005-2014) [New bird records in Tunisia (2005-2014)]. - Alauda 83: 7-28. (in French with English Summary)

Cepák, J. P. 2008. Spoonbill. - In: Cepák, J., Klvaňa, P., Škopek, J., Schröpfer, L., Jelínek, M,. Hořák, D., Formánek, J. \& Zárybnický, J. (eds.) 2008. Atlas migrace ptáku Ceské a Slovenské Republiky [Czech and Slovak bird migration atlas]. - Aventinum, Praha, pp. 268-269. (in Czech with English Summary)

Cramp, S. \& Simmons, K. E. L. 1977. The birds of the western Palearctic. Vol. 1. Ostrich to Ducks. - Oxford University Press, Oxford

de le Court, C. \& Aguilera, E. 1997. Dispersal and migration in Eurasian Spoonbills Platalea leucorodia. - Ardea 85: 193-202.

Desholm, M. \& Kahlert, J. 2005. Avian collision risk at an offshore wind farm. - Biology Letters 1(3): 296-298. DOI: 10.1098/rsbl.2005.0336

Goodman, S. M. \& Meininger, P. L. 1989. The birds of Egypt. - Oxford University Press, Oxford, New York

Hammer, Ø., Harper, D. A. T. \& Ryan, P. D. 2001. PAST: Paleontological statistics software package for education and data analysis. - Palaeontologia Electronica 4(1): 9. http://palaeo-electronica. org/2001_1/past/issue1_01.htm

Kirby, J. S., Stattersfield, A. J., Butchart, S. H., Evans, M. I., Grimmett, R. F., Jones, V. R., O’Sullivan, J., Tucker, G. M. \& Newton, I. 2008. Key conservation issues for migratory land- and waterbird species on the world's major flyways. - Bird Conservation International 18(1): 49-73. DOI: 10.1017/ S0959270908000439

Kiss, J. B., Sándor, D. A., Marinov, E. M. \& Overdijk, O. 2007. New data regarding the migration of Spoonbills (Platalea leucorodia) breeding in the Danube Delta, based on color ring resightings. - Scientific Annals of Danube Delta Institute 13: 45-50.

Kralj, J., Žuljević, A., Mikuska, T. \& Overdijk, O. 2012. Movements of immature Eurasian Spoonbills Platalea leucorodia from the breeding grounds of the Eastern metapopulation in the Pannonian Basin. - Waterbirds 35(2): 239-247. DOI: 10.1675/063.035.0206

Lok, T., Overdijk, O., Tinbergen, J. M. \& Piersma, T. 2011. The paradox of Spoonbill migration: most birds travel to where survival rates are lowest. - Animal Behaviour 82(4): 837-844. DOI: 10.1016/j.anbehav.2011.07.019

Lok, T. 2013. Spoonbills as a model system: a demographic cost-benefit analysis of differential migration. - PhD Thesis, University of Groningen, Groningen, The Netherlands

Navedo, J. G., Masero, J. A., Overdijk, O., Orizaola, G. \& Sánchez-Guzmán, J. M. 2010a Assessing the role of multiple environmental factors on Eurasian Spoonbill departure decisions from stopover sites. - Ardea 98(1): 3-12. DOI: 10.5253/078.098.0102

Navedo, J. G., Orizaola, G., Masero, J. A., Overdijk, O. \& Sánchez-Guzmán, J. M. 2010b Long-distance travellers stopover for longer: a case study with Spoonbills staying in North Iberia. - Journal of Ornithology 151(4): 915-921. DOI 10.1007/ s10336-010-0530-z

Newton, I. 2008. The ecology of bird migration. Academic Press, London

Nilsson, C., Klaassen, R. H. \& Alerstam, T. 2013. Differences in speed and duration of bird migration between spring and autumn. - The American Naturalist 181(6): 837-845. DOI: 10.1086/670335

Overdijk, O. \& Navedo, J. G. 2012. A massive Spoonbill stopover episode: identifying emergency sites for the conservation of migratory waterbird populations. - Aquatic conservation: marine and freshwater ecosystems 22(5): 695-703. DOI: 10.1002/ aqc. 2275

Palatitz, P., Solt, Sz., Fehérvári, P., Ezer, Á. \& Bánfi, P. 2009. Az MME Kékvércse-védelmi Munkacsoport beszámolója - a LIFE project (20062009) föbb eredményei [Annual report of the MME/BirdLife Hungary Red-footed Falcon Conservation Working Group]. - Heliaca 7: 14-23. (in Hungarian with English Summary)

Pigniczki, Cs. 2009. Kanalasgém (Platalea leucorodia) [Spoonbill (Platalea leucorodia)]. - In: Csörgö, T., Karcza, Zs., Halmos, G., Magyar, G., Gyurácz, J., Szép, T., Bankovics, A., Schmidt, A. \& Schmidt, E. (eds.) Magyar madárvonulási atlasz [Hungarian Bird Migration Atlas]. - Kossuth Kiadó Zrt., Budapest, pp. 195-198. (in Hungarian with English Summary)

Pigniczki, Cs. 2010. Magyarországi kanalasgémek (Platalea leucorodia) kóborlása és vonulása 


\section{Cs. Pigniczki, J. Kralj, S. Volponi, A. Žuljević, M-A. Dakhli, T. Mikuska, H. Azafzaf \& Zs. Végvári}

fémgyürüs megkerülések alapján [Dispersion and migration of Hungarian Spoonbills (Platalea leucorodia) based on recoveries of metal-ringed individuals]. - Aquila 116-117: 17-32. (in Hungarian with English Summary)

Pigniczki, Cs. 2015. A magyar gyürüs kanalasgémek (Platalea leucorodia) diszperziója és vonulása [Dispersal and migration of Spoonbills (Platalea leucorodia) ringed in Hungary]. - PhD Thesis, Debreceni Egyetem, Debrecen (in Hungarian with English Summary)

Pigniczki, Cs. \& Karcza, Zs. 2013. Movements of Eurasian Spoonbill based on metal- and colour-ringing recoveries between 1908 and 2012. in Hungary. - In: Navedo, J. G. (ed.) Proceedings of the Eurosite VII. Spoonbill Workshop, Cantabria, Spain, pp. 59-65.

Pigniczki, Cs. \& Végvári, Zs. 2015. Dispersal of the Central European population of the Eurasian Spoonbill Platalea leucorodia. - Ardeola 62(2): 219-236. DOI: 10.13157/arla.62.2.2015.3

Pigniczki, Cs., Mikuska, T., Nagy, Sz., Bino, T., Kotrošan, D., Šarac, M., Sackl, P., Saveljić, D., Feltrup-Azafzaf, C., Smart, M., Emiliani, D., Durst, R. \& Navedo, J. G. in press. Improving connectivity for the conservation of the Central European population of the Eurasian Spoonbill: conclusions from the $2^{\text {nd }}$ Adriatic Flyway Conference. - In: Sackl, P. \& Ferger, S. (eds.) Proceedings of the $2^{\text {nd }}$ Adriatic Flyway Conference, Durres, Albania 2014. - EuroNatur Radolfzell

Prommer, M., Bagyura, J., Chavko, J. \& Uhrin, M. 2012. Migratory movements of the Central European Saker Falcons (Falco cherrug) from juvenile dispersal to adulthood. - Aquila 119: 111-133.

Sackl, P., Schneider-Jacoby, M. \& Stumberger, B. 2014. Planbeobachtungen des sichtbaren Vogelzuges vor dem Bojana-Buna-Delta (Montenegro/Albanien) an der südöstlichen Adria im März 2010 [A study of visible bird migration in the delta of the Bojana-Buna River (Montenegro/Albania) off the south-eastern coast of the Adriatic Sea in March 2010]. - Der Ornithologische Beobachter 111: 187-232. (in German with English Summary)

Salewski, V. \& Bruderer, B. 2007. The evolution of bird migration - a synthesis. - Naturwissenschaften 94(4): 268-279. DOI: 10.1007/s00114-0060186-y

Schneider-Jacoby, M. 2008. How many birds migrate over the Adriatic Sea? - Acrocephalus 29: 1-3.

Shirihai, H., Dovrat, E., Christie, D. A. \& Harris, A. 1996. The birds of Israel. - Academic Press, London

Smart, M., Azafzaf, H. \& Dlensi, H. 2007. The Eurasian Spoonbill (Platalea leucorodia) in Africa.
- Ostrich 78(2): 495-500. DOI: 10.2989/OSTRICH.2007.78.2.60.174

Spina, F. \& Volponi, S. 2008. Atlante della migrazione degli uccelli in Italia. Vol. 1. Non Passeriformi [Italian Bird Migration Atlas]. - ISPRA - MATTM, Roma (in Italian with English Summary)

Strandberg, R., Klaassen, R. H., Hake, M. \& Alerstam, T. 2009. How hazardous is the Sahara Desert crossing for migratory birds? Indications from satellite tracking of raptors. - Biology Letters 6(3): 297-300. DOI: 10.1098/rsbl.2009.0785

Stroud, D. A., Davidson, N. C., West, R., Scott, D. A., Haanstra, L., Thorup, O., Ganter, B. \& Delany, S. 2004. Status of migratory wader populations in Africa and Western Eurasia in the 1990s. - International Wader Study Group 15: 1-259.

Stumberger, B. \& Schneider-Jacoby, M. 2010. Importance of the Adriatic Flyway for Common Crane (Grus grus). - Proceedings $7^{\text {th }}$ European Crane Conference, Crane conservation, Groß Mohrdorf, Germany, pp. 14-17.

Stumberger, B., Sackl, P., Božič, L., Lukač, G., Kotrošan, D., Jovičević, J., Velevski, M., Kitonić, D., Schneider-Jacoby, M. \& Durst, R. 2013. Stopover sites and migrating seasons of Eurasian Spoonbills in the eastern Adriatic region and the Dinaric Karst. - In: Navedo, J. G. (ed.) Proceedings of the Eurosite VII. Spoonbill Workshop, Cantabria, Spain, pp. 53-58.

Triplet, P., Overdijk, O., Smart, M., Nagy, Sz., Schneider-Jacoby, M., Sühendan Karauz, E., Pigniczki, Cs., Baha El Din, S., Kralj, J., Sándor, A. \& Navedo, J. G. 2008. International Single Species Action Plan for the Conservation of the Eurasian Spoonbill. - AEWA Technical Series 35.

Volponi, S., Emiliani, D. \& Fasola, M. 2008. An overview of Spoonbills in Italy. - Eurosite Spoonbill Working Group Newsletter 5: 3-5.

Warnock, N. 2010. Stopping vs. staging: the difference between a hop and a jump. - Journal of Avian Biology 41(6): 621-626. DOI: 10.1111/j.1600048X.2010.05155.X

Zenatello, M., Baccetti, N. \& Borghesi, F. 2014. Risultati dei censimenti degli uccelli acquatici svernanti in Italia. Distribuzione, stima e trend delle popolazioni nel 2001-2010 [Results of the census of wintering waterfowl in Italy. Distribution, estimates and population trends in 2001-2010]. - ISPRA Serie Rapporti, 206/2014. (in Italian)

Zwarts, L., Bijlsma, R. G., van der Kamp, J. \& Wymenga, E. 2009. Living on the edge: wetlands and birds in a changing Sahel. - Zeist: KNNV Publishing 